\title{
Lower barriers to primary care after the implementation of the Affordable Care Act in the United States of America
}

\author{
Arturo Vargas Bustamante ${ }^{1}$ and Jie Chen ${ }^{2}$
}

Suggested citation Vargas Bustamante A, Chen J. Lower barriers to primary care after the implementation of the Affordable Care Act in the United States of America. Rev Panam Salud Publica. 2018;42:e106. https://doi.org/10.26633/RPSP.2018.106

ABSTRACT Objective. To examine short-term changes in perceived barriers to access to primary care before and after implementation of the Affordable Care Act (ACA) among adults in the United States of America.

Methods. The ACA was approved in 2010. We used the National Health Interview Survey (NHIS) for the years 2011-2014 to compare the main reported problems in accessing primary care among adult respondents in 2011-2013 (before implementation of mandatory ACA health insurance for individuals) and in 2014 (after that implementation). A multivariate logistic stepwise regression analysis was used to identify trends with primary care barriers.

Results. We found that from 2010 through 2014, individuals were progressively less likely to report challenges to accessing care, such as having trouble finding a provider, getting accepted as new patients, and health care providers not accepting their health insurance. In addition, adults were less likely to report inconveniences linked to waiting times for an appointment and with provider's office hours.

Conclusions. Informing policymakers, providers, and system administrators about the short-term changes in perceived barriers to care offers a baseline for evaluating policies and programs linked to implementing the ACA, as well as assessing how prepared primary care networks were for the influx of newly insured patients. Nevertheless, the abolition of the ACA health insurance mandate through legislation approved in December 2017 has put into question whether patients' perceptions of improved access to care will be sustained in the future.

Keywords Primary health care; health services accessibility; health care reform; United States.

University of California Los Angeles, Fielding School of Public Health, Department of Health Policy and Management, Los Angeles, California, United States of America. Send correspondence to Arturo Vargas Bustamante at avb@ ucla.edu

2 University of Maryland, Department of Health Services Administration, College Park, Maryland, United States of America.
Previous research has shown that lacking health insurance coverage is strongly associated with reduced health care access and utilization and increased health care disparities (1-5). In the United States of America, the Affordable Care Act (ACA) was approved in 2010.
The uninsured population in the country declined from $18 \%$ to $12 \%$ between the initial rollout of the ACA, beginning in 2011, and the implementation of its health insurance mandate for individuals in 2014 (6). Between 2013 and 2015, approximately 16.9 million individuals 
gained health insurance coverage under the ACA health insurance expansion (7).

Various studies have linked the implementation of different ACA provisions with short-term improvements in access to care, prescription drug use, and health outcomes, as well as a decline in health care disparities $(5,8-11)$. With the rollout of the ACA, primary care providers in the United States expected to treat an increased number of newly insured patients. Policymakers and health care administrators implemented health care delivery models such as patient-centered medical homes and accountable care organizations to improve health care coordination and offer more expedient access to care $(5,8)$. During this rollout period, government programs also offered incentives for the adoption of electronic health records (12). Nevertheless, how patients perceived access to primary care providers after the ACA was implemented remains an open question.

Studies exploring the short-term impacts of the ACA on primary care barriers have focused on providers. A recent study that examines experiences and attitudes of primary care providers since the major provisions of the ACA were implemented reports an increased number of new patients (13). Health care providers also report that increased demand from new patients has not compromised their ability to deliver quality care (13). A survey by Covered California, the state's health insurance exchange, found that consumers faced some challenges understanding cost-sharing responsibilities and health plan networks, but consumers had generally positive experiences with their primary care providers (14). A positive patient experience in the first care contact is important, as it would encourage patients to use primary care services and seek appropriate care in the early stages of potentially costly and deteriorating health conditions.

To our knowledge, this study is among the first ones to analyze perceived access-to-care barriers from the patient perspective, by using a nationally representative survey for the United States. We also explore the main predictors associated with patients' reported barriers to primary care from 2011 through 2014 (the year of the implementation of its health insurance mandate). Considering that, after the approval of the ACA in 2010, health care providers had four years to prepare for an increased surge of patients and had access to government support for that, we hypothesized that perceived access to primary care improved or remained unchanged a year after the ACA health insurance mandate was implemented. Our study should prove useful to policymakers, providers, and system administrators interested in tracking the progress of ACA implementation in primary care practices.

\section{METHODS}

\section{Data}

This study employed the National Health Interview Survey (NHIS) for the years 2011-2014. The NHIS is a nationally representative annual survey of the civilian noninstitutionalized population in the United States. The NHIS provides information on a broad range of health care topics and socioeconomic and demographic characteristics of survey respondents. Adults 18-64 years of age are the study population. All adults in this age range were included in our statistical analyses, given that the ACA health insurance mandate and most of the other ACA-related policies and programs, such as health insurance exchanges and the expansion of Medicaid, targeted this population cohort. (Medicaid is a public health insurance plan for low-income populations. The program is administered by state governments but jointly funded by the federal and state governments.)

\section{Barriers to primary care}

The main outcome measures of the statistical analyses utilized the answers to the following questions from the NHIS: if respondents had trouble finding a doctor/provider, whether a provider's office accepted new patients, and if that office accepted the patients' health insurance. Additional questions that were used in the analyses were whether individuals could get through on the phone to their providers, if they were able to schedule an appointment soon enough, if they waited too long in a provider's office, if the office was open when patients could go, and whether they experienced transportation challenges.

\section{Before and after comparison}

Variable years are the main explanatory variables. They are used to compare access to primary care before and after the implementation of the ACA health insurance mandate in 2014. The variable years of 2011, 2012, and 2013 correspond to the adaptation period between the rollout of the ACA, beginning in 2011, and when the health insurance mandate took effect on 1 January 2014. We use 2011 as the reference year in the statistical analyses.

\section{Other covariates}

Our study includes additional covariates that have been identified by the previous literature to affect health care access and utilization, including socioeconomic and demographic variables. According to the Andersen behavioral model, health care access and utilization are determined by predisposing, enabling, and need factors (15). Our empirical analyses use this framework to guide model specification. Thus, predisposing factors in our models include gender, marital status, race/ethnicity, age, citizenship, education, and language of interview. Enabling factors include type of health insurance coverage, income, and region of residence. Need factors are captured by self-perceived health status and reported chronic condition.

\section{Statistical analyses}

An initial analysis provides summary statistics for each outcome measure and shows how barriers to primary care changed from 2011 to 2014. In a figure, we depict the evolution of perceived access to primary care before and after the ACA implementation for each outcome measure. This first approximation, however, does not address other confounding factors. Thus, further statistical analysis is needed to identify changes in perceived access to care. A comparison of means analysis of the study outcomes compares outcomes in 2011-2013 (before the ACA insurance mandate implementation) and 2014 (after the insurance mandate implementation). $P$ values are included for variables where statistically significant variables are identified.

A multivariate logistic stepwise regression analysis is used to identify trends in perceived primary care barriers from the initial rollout of the ACA up through the implementation of its health insurance mandate in 2014. In this model, 2011 is used as reference year. The stepwise regression analyses run 
four separate regressions for each outcome measure, including different sets of control variables, totaling 32 separate regressions. Given the length of this analysis, complete results are included in a supplementary appendix.

The purpose of this stepwise approach is to determine any possible associations with predisposing, enabling, and need factors related with changes in perceived access to care after the ACA implementation. The first regression model for each outcome measure includes predisposing factors (i.e., gender, marital status, race/ ethnicity, age, and citizenship status). The second model appends to the first regression model enabling factors (i.e., income, education, survey response language, region of residence). The third model adds to the second model need factors such as self-reported health status and reported chronic conditions. The fourth model appends health insurance status (i.e., private, Medicaid, other).

The fourth regression model for each outcome measure controls for all covariates to examine predictors associated with changes in primary care barriers. This empirical approach is also useful as a sensitivity analysis since it tests for the robustness of our main results using different sets of covariates. Outcomes that remain significantly different after the inclusion of different sets of covariates would be considered robust. In addition, we include $95 \%$ confidence intervals (CIs) in our regression analysis. The statistical analyses include sampling weights to estimate nationally representative results. We used Stata 13 statistical software and included survey weights (i.e., performed "svy" commands) to conduct all statistical analyses.

\section{RESULTS}

Table 1 summarizes perceived primary care barriers from 2011 through 2014. In comparison to the 2011 reference year, measures of perceived barriers to access to primary care showed reductions in the following years, during the rollout of the ACA and also in 2014, when the implementation of the health insurance mandate occurred. In 2014 as compared to 2011, fewer respondents reported trouble finding a doctor/provider (reduction of 0.63 percentage points), getting accepted as a new patient ( 0.73 percentage points), and having their health care providers accept their health insurance (0.63 percentage points). Over that same period, adults also reported fewer delays getting through on the phone (decrease of 0.30 percentage points), getting an appointment soon enough (0.72 percentage points), and waiting too long at the provider's office (1.49 percentage points). Similarly, the share of adults reporting that providers were not open when they could go or that they faced transportation challenges dropped by 0.74 percentage points and 0.23 percentage points, respectively.

Figure 1 shows the evolution of perceived primary care barriers from 2011 to 2014, ranked by the frequency of each barrier. Getting an appointment soon enough continued to be the main hurdle reported by respondents from 2011 to 2014, although its incidence declined each year. Transportation was the least prevalent barrier, although it marginally increased from 1.99 percentage points in 2013 to 2.04 percentage points in 2014.

Two additional measures also increased in 2014 after three years of consecutive declines. First, the share of adults reporting trouble finding a doctor/provider increased from 2.82 percentage points in 2013 to 2.91 percentage points in 2014 . Second, the share of individuals reporting that the doctor's office did not accept their health insurance increased from 2.98 percentage points in 2013 to 3.08 percentage points in 2014.

Table 2 compares the perceived barriers to primary care before (2011-2013) and after (2014) the implementation of the ACA health insurance mandate. The $P$ values in Table 2 report on the five primary care barriers that showed statistically significant differences after the implementation of the ACA health insurance mandate: not getting accepted as a new patient, health care providers not accepting the patient's health insurance, not getting an appointment soon enough, waiting too long at the provider's office, and the deficiency in office hours when patients could attend. (For clarity and simplicity, $P$ values that are not statistically significant are not shown in Table 2.) Importantly, mean values were consistently lower for all statistically significant values after the implementation of the ACA health insurance mandate.

The results from the differences in the means analysis are indicative of perceived reductions in primary care barriers that may have changed as a consequence of the implementation of the ACA health insurance mandate. These results, however, do not account for potential confounders. A stepwise multivariate regression approach is needed to take these covariates into consideration and determine whether identified statistically significant differences are robust to the inclusion of different enabling, predisposing, and need factors. Consequently,

TABLE 1. Share of adults reporting barriers to primary care before (2011-2013) and after (2014) the implementation of the health insurance mandate of the Affordable Care Act (ACA) in the United States ${ }^{a}$

\begin{tabular}{|c|c|c|c|c|}
\hline Barrier & $\begin{array}{c}2011 \text { mean }(\%) \\
(\mathrm{N}=22083)\end{array}$ & $\begin{array}{c}2012 \text { mean }(\%) \\
(\mathrm{N}=22862)\end{array}$ & $\begin{array}{c}2013 \text { mean }(\%) \\
(N=22586)\end{array}$ & $\begin{array}{c}2014 \text { mean }(\%) \\
(\mathrm{N}=24149)\end{array}$ \\
\hline Trouble finding a doctor/provider & 3.54 & 3.12 & 2.82 & 2.91 \\
\hline Doctor's office does not accept you as new patient & 3.07 & 2.57 & 2.39 & 2.34 \\
\hline Doctor's office does not accept your health insurance & 3.70 & 3.42 & 2.98 & 3.08 \\
\hline Couldn't get through on the phone & 2.59 & 2.53 & 2.43 & 2.29 \\
\hline Couldn't get appointment soon enough & 6.37 & 6.46 & 5.95 & 5.65 \\
\hline Wait too long in doctor's office & 4.93 & 4.31 & 3.81 & 3.44 \\
\hline Not open when you could go & 3.43 & 3.40 & 3.03 & 2.69 \\
\hline No transportation & 2.27 & 2.08 & 1.99 & 2.04 \\
\hline
\end{tabular}

Source: Prepared by the authors using data from the National Health Interview Survey (NHIS) for the years 2011-2014.

a The statistical analysis uses population weights and includes adults ages 18-64. "Before" corresponds to mean values for the years 2011-2013, that is, the period before the

implementation of the ACA individual health insurance mandate. "After" corresponds to mean values for the year 2014, the first year of the ACA individual health insurance mandate. 
FIGURE 1. Frequency (percentage) of perceived barriers to primary care before (2011-2013) and after (2014) the implementation of the health insurance mandate of the Affordable Care Act (ACA) in the United States ${ }^{a}$

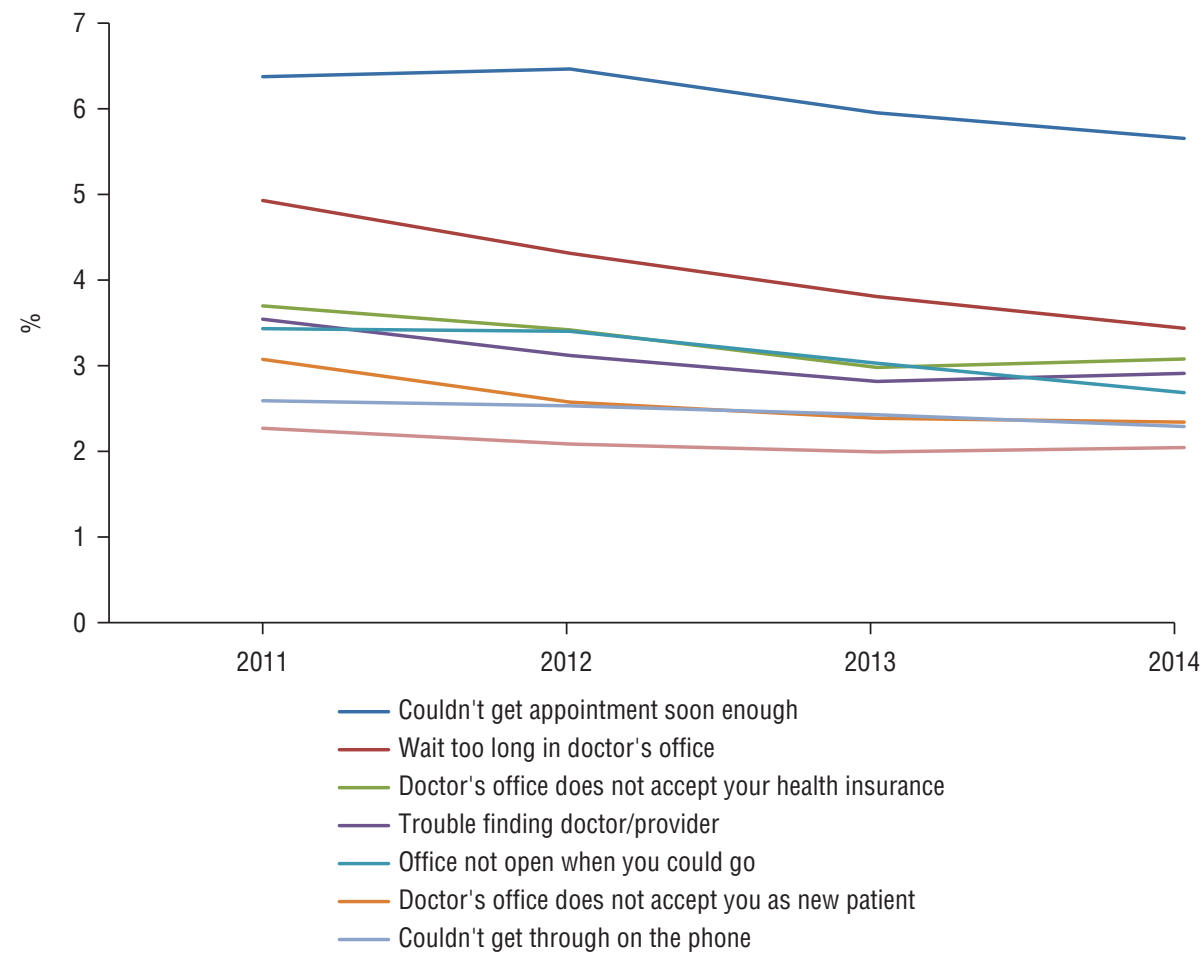

Source: Prepared by the authors using data from the National Health Interview Survey (NHIS) for the years 2011-2014.

a The statistical analysis uses population weights and includes adults ages 18-64. "Before" corresponds to mean values for the years 2011-2013, that is, the period before the implementation of the ACA individual health insurance mandate. "After" corresponds to mean values for the year 2014, the first year of the ACA individual health insurance mandate.

TABLE 2. Analysis of differences in means of barriers to primary care before (2011-2013) and after (2014) the implementation of the Affordable Care Act (ACA) health insurance mandate in the United States ${ }^{a}$

\begin{tabular}{lccc}
\hline Barrier & $\begin{array}{c}2011-2013 \text { mean } \\
(\%)\end{array}$ & $\begin{array}{c}2014 \text { mean } \\
(\%)\end{array}$ & $P$ value \\
\hline Trouble finding a doctor/provider & 3.16 & 2.91 & \\
Doctor's office does not accept you as new patient & 2.68 & 2.34 & $<0.05$ \\
Doctor's office does not accept your health insurance & 3.37 & 3.08 & $<0.05$ \\
Couldn't get through on phone & 2.52 & 2.29 & \\
Couldn't get appointment soon enough & 6.26 & 5.65 & $<0.01$ \\
Wait too long in doctor's office & 4.35 & 3.44 & $<0.001$ \\
Not open when you could go & 3.29 & 2.69 & $<0.001$ \\
No transportation & 2.12 & 2.04 & \\
\hline
\end{tabular}

Source: Prepared by the authors using data from the National Health Interview Survey (NHIS) for the years 2011-2014.

a The statistical analysis uses population weights and includes adults ages 18-64. "Before" corresponds to mean values for the years 2011-2013, the period before the implementation of the ACA individual health insurance mandate. "After" corresponds to mean values for the year 2014, the first year of the ACA individual health insurance mandate. $P$ values that are not statistically significant are not shown.

in Table 3 we summarize the main outcomes of the stepwise multivariate logistic regression analyses identifying differences in perceived barriers to primary care from 2012 through 2014. In these regression models we use 2011 as the reference year.
The results in Table 3 highlight the main findings from the full stepwise regression analyses that are available in the supplementary Statistical Appendix. Table 3 shows the regression model that includes all predisposing factors (i.e., gender, marital status, race/ethnicity, age, and citizenship status), enabling factors (i.e., income, education, survey response language, region of residence), and need factors (i.e., perceived health status, reported chronic conditions, and type of health insurance coverage). To provide more detailed results, Table 3 also includes covariates that were consistently statistically significant in the stepwise regression analyses (see the supplementary Statistical Appendix).

Compared to the reference group (i.e., 2011), adults report lower odds in 2012, 2013, and 2014 of having trouble finding a doctor/provider (95\% CI in $2012=$ $0.78-1.00$; $95 \%$ CI in $2013=0.71-0.90 ; 95 \%$ $\mathrm{CI}$ in $2014=0.76-0.97)$; getting accepted as a new patient $(95 \% \mathrm{CI}$ in $2012=0.73$ 0.96 ; $95 \% \mathrm{CI}$ in $2013=0.68-0.90 ; 95 \% \mathrm{CI}$ in $2014=0.67-0.88)$; health care providers not accepting their health insurance $(95 \%$ $\mathrm{CI}$ in $2013=0.70-0.91 ; 95 \% \mathrm{CI}$ in $2014=$ 0.73-0.91); not getting an appointment soon enough $(95 \%$ CI in $2014=0.80-0.97)$; waiting too long in the doctor's office $(95 \%$ CI in $2013=0.68-0.84 ; 95 \%$ CI in $2014=0.61-0.75)$; and there not being office hours when patients could go $(95 \%$ CI in $2014=0.69-0.89)$. The differences across 2012, 2013, and 2014 versus 2011 for adults reporting that they could not get through on the phone or that they had transportation problems were not statistically significant.

Female adults consistently reported higher odds $(\mathrm{OR}>1)$ of encountering perceived barriers to primary care, as compared to males. In contrast, married individuals reported lower odds (OR < 1) of experiencing perceived primary care barriers, with the exception of waiting times at doctor's office and a lack of office hours when patients could be seen. Compared to the uninsured reference category, privately insured patients reported statistically significant lower odds $(\mathrm{OR}<1)$ of having trouble finding a doctor/provider, getting accepted as a new patient, health care providers not accepting their health insurance, and having transportation problems. In contrast, the insured patients reported statistically higher odds $(\mathrm{OR}>1)$ of not getting an appointment soon enough and of a lack of opening hours when patients could go. The proportions of privately insured adults who reported they waited too long in the doctor's office or that they could not get through on the phone were not statistically different. 
TABLE 3. Multivariate analysis of barriers to primary care before (2011-2013) and after (2014) the implementation of the health insurance mandate of the Affordable Care Act (ACA) in the United States ${ }^{a}$

\begin{tabular}{|c|c|c|c|c|c|c|c|c|c|c|c|c|}
\hline & \multicolumn{3}{|c|}{$\begin{array}{l}\text { Trouble finding a } \\
\text { doctor/provider }\end{array}$} & \multicolumn{3}{|c|}{$\begin{array}{c}\text { Doctor's office does not accept } \\
\text { you as new patient }\end{array}$} & \multicolumn{3}{|c|}{$\begin{array}{l}\text { Doctor's office does not accept } \\
\text { your health insurance }\end{array}$} & \multicolumn{3}{|c|}{$\begin{array}{l}\text { Couldn't get through } \\
\text { on phone }\end{array}$} \\
\hline & $\mathrm{OR}^{\mathrm{b}}$ & $95 \% \mathrm{Cl}^{\mathrm{c}}$ & $P$ & $\mathrm{OR}$ & $95 \% \mathrm{Cl}$ & $P$ & $\mathrm{OR}$ & $95 \% \mathrm{Cl}$ & $P$ & $\mathrm{OR}$ & $95 \% \mathrm{Cl}$ & $P$ \\
\hline 2011 & \multicolumn{3}{|c|}{ reference } & \multicolumn{3}{|c|}{ reference } & \multicolumn{3}{|c|}{ reference } & \multicolumn{3}{|c|}{ reference } \\
\hline 2014 & 0.86 & $0.76-0.97$ & 0.01 & 0.77 & $0.67-0.88$ & 0.00 & 0.81 & $0.73-0.91$ & 0.00 & 0.89 & $0.78-1.01$ & 0.08 \\
\hline 2013 & 0.80 & $0.71-0.90$ & 0.00 & 0.78 & $0.68-0.90$ & 0.00 & 0.80 & $0.70-0.91$ & 0.00 & 0.95 & $0.83-1.08$ & 0.42 \\
\hline 2012 & 0.88 & $0.78-1.00$ & 0.04 & 0.84 & $0.73-0.96$ & 0.01 & 0.92 & $0.82-1.04$ & 0.17 & 0.98 & $0.85-1.13$ & 0.76 \\
\hline Female & 1.29 & $1.18-1.42$ & 0.00 & 1.48 & $1.33-1.65$ & 0.00 & 1.53 & $1.39-1.69$ & 0.00 & 1.58 & $1.42-1.77$ & 0.00 \\
\hline Married & 0.88 & $0.79-0.98$ & 0.02 & 0.86 & $0.77-0.96$ & 0.01 & 0.84 & $0.76-0.92$ & 0.00 & 0.89 & $0.79-1.00$ & 0.04 \\
\hline \multicolumn{13}{|l|}{ Health insurance } \\
\hline Uninsured & \multicolumn{3}{|c|}{ reference } & \multicolumn{3}{|c|}{ reference } & \multicolumn{3}{|c|}{ reference } & \multicolumn{3}{|c|}{ reference } \\
\hline Private & 0.35 & $0.31-0.40$ & 0.00 & 0.47 & $0.41-0.55$ & 0.00 & 0.77 & $0.67-0.88$ & 0.00 & 0.91 & $0.79-1.05$ & 0.19 \\
\hline Medicaid & 0.59 & $0.51-0.68$ & 0.00 & 1.12 & $0.95-1.31$ & 0.17 & 1.93 & $1.69-2.22$ & 0.00 & 1.24 & $1.04-1.48$ & 0.02 \\
\hline Other & 0.53 & $0.44-0.64$ & 0.00 & 0.69 & $0.57-0.84$ & 0.00 & 1.43 & $1.21-1.68$ & 0.00 & 1.28 & $1.04-1.57$ & 0.02 \\
\hline \multirow[t]{3}{*}{ Other covariates } & Yes & & & Yes & & & Yes & & & Yes & & \\
\hline & \multicolumn{3}{|c|}{$\begin{array}{l}\text { Couldn't get appointment } \\
\text { soon enough }\end{array}$} & \multicolumn{3}{|c|}{$\begin{array}{l}\text { Wait too long in } \\
\text { doctor's office }\end{array}$} & \multicolumn{3}{|c|}{$\begin{array}{l}\text { Not open when } \\
\text { you could go }\end{array}$} & \multicolumn{3}{|c|}{ No transportation } \\
\hline & OR & $95 \% \mathrm{Cl}$ & $P$ & OR & $95 \% \mathrm{Cl}$ & $P$ & OR & $95 \% \mathrm{Cl}$ & $P$ & $\mathrm{OR}$ & $95 \% \mathrm{Cl}$ & $P$ \\
\hline 2011 & \multicolumn{3}{|c|}{ reference } & \multicolumn{3}{|c|}{ reference } & \multicolumn{3}{|c|}{ reference } & \multicolumn{3}{|c|}{ reference } \\
\hline 2014 & 0.88 & $0.80-0.97$ & 0.01 & 0.67 & $0.61-0.75$ & 0.00 & 0.79 & $0.69-0.89$ & 0.00 & 0.89 & $0.76-1.04$ & 0.14 \\
\hline 2013 & 0.94 & $0.86-1.03$ & 0.20 & 0.76 & $0.68-0.84$ & 0.00 & 0.90 & $0.80-1.02$ & 0.10 & 0.88 & $0.76-1.02$ & 0.10 \\
\hline 2012 & 1.02 & $0.93-1.12$ & 0.69 & 0.86 & $0.77-0.96$ & 0.01 & 0.99 & $0.89-1.11$ & 0.92 & 0.91 & $0.79-1.05$ & 0.20 \\
\hline Female & 1.48 & $1.39-1.58$ & 0.00 & 1.25 & $1.15-1.36$ & 0.00 & 1.32 & $1.20-1.44$ & 0.00 & 1.24 & $1.10-1.39$ & 0.00 \\
\hline Married & 0.94 & $0.88-1.00$ & 0.05 & 0.98 & $0.90-1.06$ & 0.61 & 0.96 & $0.86-1.07$ & 0.46 & 0.52 & $0.46-0.59$ & 0.00 \\
\hline \multicolumn{13}{|l|}{ Health insurance } \\
\hline Uninsured & \multicolumn{3}{|c|}{ reference } & \multicolumn{3}{|c|}{ reference } & \multicolumn{3}{|c|}{ reference } & \multicolumn{3}{|c|}{ reference } \\
\hline Private & 1.27 & $1.15-1.39$ & 0.00 & 1.01 & $0.91-1.13$ & 0.85 & 1.17 & $1.03-1.34$ & 0.02 & 0.54 & $0.45-0.64$ & 0.00 \\
\hline Medicaid & 1.34 & $1.18-1.51$ & 0.00 & 1.27 & $1.11-1.44$ & 0.00 & 0.99 & $0.84-1.17$ & 0.93 & 1.24 & $1.07-1.43$ & 0.00 \\
\hline Other & 1.74 & $1.53-1.98$ & 0.00 & 1.23 & $1.07-1.42$ & 0.00 & 1.17 & $0.98-1.39$ & 0.09 & 1.42 & $1.19-1.68$ & 0.00 \\
\hline Other covariates & \multicolumn{3}{|l|}{ Yes } & Yes & & & Yes & & & Yes & & \\
\hline $\begin{array}{l}\text { Source: Prepared } \\
\text { The statistical ana } \\
\text { implementation of } \\
\text { Other covariates inc } \\
\text { Full results and ste } \\
{ }^{\mathrm{D}} \mathrm{OR}=\text { odds ratio. }\end{array}$ & $\begin{array}{l}\text { Ils are } \\
\text { itivity a }\end{array}$ & $\begin{array}{l}\text { /ethnicity, ag } \\
\text { yses are avail }\end{array}$ & in the & plemer & $\begin{array}{l}\text { Ication, langu } \\
\text { Statistical Ap }\end{array}$ & $\begin{array}{l}\text { of inte } \\
\text { dix. }\end{array}$ & -2014. & residence, he & statu & d chror & $\begin{array}{l}\text { before the } \\
\text { urance mand } \\
\text { conditions. }\end{array}$ & \\
\hline
\end{tabular}

In comparison to the uninsured reference category, adults insured by Medicaid reported statistically significant lower odds of having trouble finding a doctor/provider. They reported higher odds (OR $>1$ ) of health care providers not accepting their health insurance, of not getting through on the phone, of not scheduling an appointment soon enough, and of having transportation problems. For Medicaid-insured adults, there were no statistically significant differences in the proportions reporting trouble being accepted as new patients or saying providers' offices were not open when they could go.

Adults with some other type of insurance coverage reported statistically significant lower odds $(\mathrm{OR}<1)$ of having trouble finding a doctor/provider and of being accepted as new patients. However, they also reported higher odds (OR $>1$ ) of health care providers not accepting their health insurance, not getting through on the phone, not obtaining an appointment soon enough, waiting too long in the doctor's office, and having transportation problems. Individuals with "other" insurance reporting trouble with provider's opening hours were not statistically different.

\section{DISCUSSION}

After the ACA's approval in 2010, policymakers questioned the capability of the primary care delivery network to administer high-quality care to an expected influx of new patients, particularly in states with the largest uninsured populations (16). Beginning in 2010, health care providers started to prepare for the full implementation of the main ACA provisions in 2014 (13). Parallel health care policies also influenced the preparedness of primary care practices during this time period, such as the widespread introduction of electronic health records and the implementation of new health care delivery models such as patient-centered medical homes and accountable care organizations $(5,8)$. External and internal transformations could have improved the preparedness of primary care practices to cope with increased demand from newly insured patients after the full implementation of the health insurance mandate in 2014.

From the perspective of perceived access to care, our results provide 
preliminary evidence that, on average, primary care providers were able to cope satisfactorily with the challenges of catering to the newly insured population. Importantly, this short-term, preliminary finding is based on the reported hurdles that patients faced when they attempted to access primary care providers. A more comprehensive impact evaluation should also look at objective measures of primary care transformations that occurred during the same period of time. Our study findings demonstrate that adults were less likely to report barriers to accessing care after the ACA's approval in 2010, and that this downward trend continued after the implementation of the health insurance mandate in 2014. These changes in perceived access to care suggest that the increasing numbers of insured individuals during this period did not affect the perception of patients in the primary care network. These findings are robust to the inclusion of different set of comparisons and to multiple sensitivity tests.

Getting an appointment soon enough was the most common challenge that adults reported when they tried to access primary care. Waiting too long at the doctor's office and inconvenient opening hours were, respectively, the second and fourth most commonly reported barriers. While the perceptions of these hurdles declined from 2010 until 2014, they continued to be substantial. To address these issues, policymakers, providers, and system administrators in the United States should accelerate current initiatives to improve access to primary care and its efficiency and quality, through the use of medical assistants, health care coordinators, and patient navigators $(17,18)$. Telemedicine also has great promise to address these challenges since it would allow patients to access primary care in a more timely and convenient manner (19). The continued growth of retail clinics could also improve accessibility (20). The combination of these transformations in primary care has great potential to improve access to primary care in the future.

Lack of insurance acceptability, trouble finding a provider, and primary care practices not being open to new patients were, respectively, the third, fifth, and sixth most widely reported primary care barriers. The share of adults reporting these hurdles increased marginally after the implementation of the health insurance mandate (2013 vs. 2014), even though our comparison of means analysis and our logistic regression analyses showed that rates were still lower in 2014 compared to the reference year of 2011. It remains unclear whether these trends continued in subsequent years as the ACA continued its implementation.

The study findings suggest that from the perspective of patients, between 2010 and 2014, primary care providers were able to cope satisfactorily with an increased demand from millions of newly insured individuals. The relative stability in the odds of adults reporting troubles with insurance eligibility and primary care practices not being open to new patients suggest that supply was not overridden by demand, even though challenges remained to adequately catering to all newly insured patients.

The type of insurance was key to understanding barriers to primary care access after the ACA implementation. Individuals who had private insurance were less likely to report barriers. In contrast, individuals with other insuranceand particularly adults with Medicaid coverage-were more likely to report hurdles in accessing primary care. New ways of incentivizing practices to accept Medicaid patients should be explored, in addition to Medicaid payment increases and outsourcing Medicaid coverage to privately managed health maintenance organizations (HMOs) with broader provider networks. Ongoing efforts to make it easier to match new patients with available providers should be encouraged, particularly with new information technologies (19).

Important covariates that were key to understanding differences in perceived barriers to primary care access were gender and marital status. Female respondents consistently reported higher odds of encountering hurdles trying to access primary care. In contrast, married individuals consistently encountered fewer hurdles. Health care and system administrators should address these important drivers of inequities and disparities in access to care.

Transportation problems and challenges getting through on the phone were the least reported issues. However, these barriers to primary care were more likely to be reported by Medicaid-insured patients. Policies aimed at expanding public transportation in urban areas could improve accessibility by low-income individuals to health care providers willing to accept Medicaid coverage. Likewise, more widespread utilization of email, provider websites, telemedicine, and other automated mechanisms to schedule primary care appointments could improve the contact links between patients and primary care providers.

The tax reform for 2018 approved by the United States Congress in December 2017 included the abolition of the ACA health insurance mandate four years after it was first implemented. While other provisions of the health care law remain in place, the abolition of its health insurance mandate weakens the incentives that previously uninsured individuals had to purchase insurance in the state and federal health insurance exchanges or to enroll in subsidized health insurance plans (i.e., Medicaid). Having fewer incentives to purchase insurance puts into question whether the patients' perceptions of improved access to care will be sustained in the future. Primary care providers in the United States will likely adapt to changes in the demand for services. If demand for primary care services declines as a consequence of this policy change, it is likely that inequities and disparities in access to care will increase in the United States health care system.

Three limitations to our analysis should be acknowledged. The study uses a repeated cross-sectional design, which limits the analyses of differences over time. Self-reported data is dependent on respondent's perspectives, which in some cases could differ from objective assessments of access to care through process and outcome measures from administrative data repositories. While the sample size for the analyses is relatively large and the statistical analyses are adequately powered, the analysis distinguishes among only four regions of the United States (i.e., Northeast, Midwest, South, and West). Further research could benefit from state-level information to account for the regional factors that influence access to primary care and patients' perspectives such as Medicaid eligibility.

\section{Conclusions}

This study finds that, from the approval of the ACA in 2010 until the implementation of its health insurance mandate in 2014, adults were progressively less likely to report barriers to primary care. These 
findings are suggestive of improved preparedness of primary care providers for an increased influx of patients between the rollout of the ACA in 2010 until the implementation of the health insurance mandate in 2014.

Future research should use objective measures (e.g., process and outcome measures from administrative data) and should address the specific impact of external forces such as new models of

1. U.S. Department of Health and Human Services. Overview of the uninsured in the United States: a summary of the 2011 Current Population Survey. Available from: https://aspe.hhs.gov/basic-report/ overview-uninsured-united-states-summary-2011-current-population-survey Accessed on 10 January 2018

2. Bustamante AV, Fang H, Rizzo JA, Ortega AN. Heterogeneity in health insurance coverage among US Latino adults. J Gen Intern Med. 2009;24 Suppl 3:561-6.

3. Ortega AN, Rodriguez HP, Vargas Bustamante A. Policy dilemmas in Latino health care and implementation of the Affordable Care Act. Annu Rev Public Health. 2015;36:525-44.

4. Rodriguez MA, Bustamante AV, Ang A. Perceived quality of care, receipt of preventive care, and usual source of health care among undocumented and other Latinos. J Gen Intern Med. 2009;24 Suppl 3:508-13.

5. Chen J, Vargas-Bustamante A, Mortensen K, Ortega AN. Racial and ethnic disparities in health care access and utilization under the Affordable Care Act. Med Care. 2016;54(2):140-6.

6. Long SK, Karpam M, Kenney G, Wissoker D, Zuckerman S, Wissoker D, et al. Health insurance coverage under the ACA as of December 2014. Washington, D.C.: Urban Institute Health Policy Center; 2015.

7. Hayes SL, Riley P, Radley DC, McCarthy D. Closing the gap: past performance of health insurance in reducing racial and ethnic disparities in access to care could be health care delivery and of internal transformations such as the widespread adoption of electronic health records. In addition, the effect in future years of abolishing the ACA health insurance mandate should be carefully evaluated using measures of access to care and patients' experiences of care.

Funding. Jie Chen acknowledges funding from the U.S. National

\section{REFERENCES}

an indication of future results. Issue Brief (Commonw Fund). 2015 Mar;5:1-11.

8. Chen J, Bustamante AV, Tom SE. Health care spending and utilization by race/ethnicity under the Affordable Care Act's dependent coverage expansion. Am J Public Health. 2015;105 Suppl 3:S499-507.

9. Sommers BD, Gunja MZ, Finegold K, Musco T. Changes in self-reported insurance coverage, access to care, and health under the Affordable Care Act. JAMA. 2015;314(4):366-74.

10. Cutler DM. From the Affordable Care Act to affordable care. JAMA. 2015; 314(4):337-8.

11. Chen J, Vargas-Bustamante A, Novak P. Reducing young adults' health care spending through the ACA expansion of dependent coverage. Health Serv Res. 2017;52(5):1835-57.

12. Fleming NS, Culler SD, McCorkle R, Becker ER, Ballard DJ. The financial and nonfinancial costs of implementing electronic health records in primary care practices. Health Aff (Millwood). 2011;30(3):481-9.

13. Hamel L, Doty M, Norton M, Ryan J, Brodie M, Abrams M, et al. Experiences and attitudes of primary care providers under the first year of ACA coverage expansion. New York: The Commonwealth Fund; 2016.

14. California Health Care Foundation. Patients and providers speak: early care experiences under the ACA. Oakland: CHCF; 2014
Institute on Minority Health and Health Disparities grant number 1R01MD011523-01.

Conflicts of interest. None declared.

Disclaimer. Authors hold sole responsibility for the views expressed in the manuscript, which may not necessarily reflect the opinion or policy of the RPSP/ PAJPH or PAHO.
15. Andersen RM. Revisiting the behavioral model and access to medical care: Does it matter? J Health Soc Behav. 1995; 36(1):1-10

16. Ku L, Jones K, Shin P, Bruen B, Hayes K. The states' next challenge-securing primary care for expanded Medicaid populations. N Engl J Med. 2011;364(6):493-5.

17. Rodriguez HP, Rogers WH, Marshall RE, Safran DG. The effects of primary care physician visit continuity on patients' experiences with care. J Gen Intern Med. 2007;22(6):787-93.

18. Rodriguez HP, Chen X, Martinez AE, Friedberg MW. Availability of primary care team members can improve teamwork and readiness for change. Health Care Manage Rev. 2016:41(4):31-7.

19. Grabowski DC, O'Malley AJ. Use of telemedicine can reduce hospitalizations of nursing home residents and generate savings for Medicare. Health Aff (Millwood). 2014;33(2):244-50

20. Weinick RM, Burns RM, Mehrotra A Many emergency department visits could be managed at urgent care centers and retail clinics. Health Aff (Millwood). 2010;29(9):1630-6.

Manuscript received on 2 June 2017. Revised version accepted for publication on 11 January 2018. 
RESUMEN

Menores barreras a la atención primaria tras la aplicación de la Ley de Atención Asequible en los Estados Unidos de América

Palabras clave
Objetivo. Analizar los cambios a corto plazo en las barreras percibidas al acceso a la atención primaria en los adultos en los Estados Unidos de América antes y después de la entrada en vigor de la Ley de Atención Asequible (ACA por su sigla en inglés).

Métodos. La ley ACA se aprobó en el 2010. Usamos la Encuesta Nacional de Salud por Entrevistas (NHIS) de los años 2011 al 2014 a fin de comparar los principales problemas mencionados para obtener acceso a la atención primaria por los adultos entrevistados del 2011 al 2013 (antes de la entrada en vigor del seguro de salud obligatorio para las personas de conformidad con la ACA) y en el 2014 (después de que entrase en vigor). Se usó un análisis de regresión logística por pasos con múltiples variables para determinar las tendencias en las barreras a la atención primaria.

Resultados. Encontramos que, del 2010 al 2014, fue progresivamente menos probable que las personas notificaran obstáculos para obtener acceso a la atención, como dificultades para encontrar un prestador o ser aceptados como nuevos pacientes, y que los prestadores de atención de salud no aceptaran su seguro de salud. Además, fue menos probable que los adultos notificaran problemas por los períodos de espera para una cita y las horas de oficina de los prestadores.

Conclusiones. Informar a los responsables de las políticas, a los prestadores y a los administradores de los sistemas acerca de los cambios a corto plazo en las barreras percibidas a la atención ofrece un punto de referencia para evaluar las políticas y programas vinculados a la aplicación de la ACA, así como para evaluar cuán preparadas estaban las redes de atención primaria para la afluencia de pacientes recién asegurados. No obstante, la abolición del mandato del seguro de salud de la ACA por la legislación aprobada en diciembre del 2017 ha puesto en entredicho si las percepciones de los pacientes de un mejor acceso a la atención se mantendrán en el futuro.

Atención primaria de salud; accesibilidad a los servicios de salud; reforma de la atención de salud; Estados Unidos.
RESUMO

Menos barreiras à atenção primária após a execução da Lei de Serviços de Saúde Acessíveis nos Estados Unidos da América

Palavras-chave
Objetivo. Examinar as mudanças a curto prazo nas barreiras percebidas entre adultos ao acesso à atenção primária antes e depois da execução da Lei de Serviços de Saúde Acessíveis (Affordable Care Act, ACA) nos Estados Unidos.

Métodos. A ACA foi aprovada em 2010. Este estudo se baseou em dados obtidos da pesquisa nacional de saúde (National Health Interview Survey, NHIS) para os anos 2011-2014 para comparar os principais problemas referidos pelos participantes adultos para obter acesso à atenção primária em 2011-2013 (antes da execução do seguro de saúde obrigatório exigido pela ACA) e em 2014 (depois da execução da lei). Foi realizada uma análise de regressão logística multivariada com o método stepwise para identificar as tendências nas barreiras à atenção primária.

Resultados. Verificou-se que, de 2010 a 2014, os participantes tenderam gradativamente a informar menos ter dificuldades de acesso à atenção, como ter dificuldade em encontrar um prestador de serviço, ser aceito como novo paciente e prestadores de serviços de saúde que não aceitam o seguro de saúde do paciente. Além disso, eles tenderam a informar menos os inconvenientes relacionados ao tempo de espera para consultas e ao horário de atendimento dos serviços.

Conclusões. Informar os responsáveis por políticas, prestadores de serviços e administradores do sistema sobre as mudanças a curto prazo nas barreiras percebidas à atenção serve de referência para avaliar as políticas e programas vinculados à execução da ACA e determinar se as redes de atenção primária têm condições adequadas para atender os novos usuários segurados. Contudo, a extinção do mandato de seguro de saúde da ACA, com a legislação aprovada em dezembro de 2017, põe em dúvida se a percepção de melhora no acesso à atenção por parte dos pacientes persistirá futuramente.

Atenção primária à saúde; acesso aos serviços de saúde; reforma dos serviços de saúde; Estados Unidos. 